\title{
Women as Opinion Leaders within Community (A Model of Feminism Perspective)
}

\section{Perempuan sebagai Pemimpin Opini dalam Komunitas (Sebuah Model Pendekatan Feminisme)}

\author{
Lasmery RM Girsang \\ Universitas Bunda Mulia, Lodan Raya No 2, North Jakarta 14430 \\ lgirsang@bundamulia.ac.id
}

\begin{abstract}
Jakarta still faced many social problems. One of them related to urban settlement so that rusunawa was created to be a solution. In the beginning-unfortunately-the government's policy had resulted in rejection among people living under the poverty line. It was caused by the difficulty of changing old habits from the previous location to a new situation. Besides that, phycological and economic burdens added serious problems for marginalized people. It happened until some women were aware of such a situation and put effort into the community. As a critical paradigm, this article discussed the Feminist Communication Theory to seek the role of voice in the construction of inequality and oppression. By using qualitative research, the results showed that through feminine transformative leadership, the informants were pushed to have abilities to communicate, dialogue, persuade, and influence the community to lead the community for having a new life world.
\end{abstract}

Keywords: Community; Feminism; Gender; Leadership; Transformative

\begin{abstract}
Abstrak
Jakarta masih menghadapi banyak masalah sosial. Salah satunya terkait dengan permukiman perkotaan sehingga rusunawa dihadirkan sebagai solusi. Namun disayangkan pada awalnya, kebijakan pemerintah justru menghasilkan penolakan di antara orang-orang yang hidup di bawah garis kemiskinan. Hal tersebut disebabkan sulitnya mengubah kebiasaan lama dari lokasi sebelumnya ke situasi baru. Selain itu, beban psikologis dan ekonomi menambah masalah serius bagi orang-orang yang terpinggirkan. Hingga beberapa wanita menyadari situasi seperti tersebut dan melakukan upaya didalam komunitas. Berangkat dari paradigma kritis, artikel ini membahas Teori Komunikasi Feminis untuk mencari peran 'suara' dalam keadaan ketidaksetaraan dan penindasan. Dengan menggunakan penelitian kualitatif, hasilnya menunjukkan bahwa melalui kepemimpinan transformatif feminin, para narasumber didorong untuk memiliki kemampuan berkomunikasi, berdialog, membujuk dan mempengaruhi masyarakat memimpin masyarakat memiliki dunia kehidupan yang baru.
\end{abstract}

Kata Kunci: Feminisme; Gender; Kepemimpinan; Komunitas; Transformatif 


\section{Introduction}

Jakarta has grown rapidly: a 'new face' of the big city grows up to be a humane city. Consequently, the government's effort in structuring urban settlement should get rid of marginal communities. The problem is that, like many developed countries, the government often neglects human rights on behalf of development. After the regulations are made to dismiss slum areas, the government of DKI Jakarta - under the leadership of Basuki Tjahja Purnama in 2015 - finally took action to 'get rid of' marginal society into new settlements. The relocation program is called rusunawa (rumah susun sederhana sewa) — a low-cost simple flat.

The policy was rejected by many people living under the poverty line. This is because people that should change their old habits from the previous location and adapt to new situations find it difficult. Furthermore, without a permanent job, the settlers are required to pay the monthly rent. Not to mention that many new residents of rusunawa are traumatized after losing homes.

Living at rusunawa equals to begin a new life in a new order/structure that could potentially impact the shift of social system. Initially, the vertical housing concept is expected to be a new residence solution to eliminate slums and wild settlement in the capital city. However, physical development should be in line with human development; in this case, marginal society should be prepared mentally to enter the new world order.

Occupied by multi-ethnic people, rusunawa is common among the less prosperous community. Working in the informal sector, most of the people are sellers (small and medium level), in which only a small group is working in the formal sector (as employees). It is found that most of the heads of the families lost the job when the eviction was executed. Undeniably, that condition pushed women as wive and mothers to look for a job to cover household needs. For doing so, women play double roles to maintain and struggle for their family's life.

Such a difficult situation in the new environment cannot be separated from the effort of community members to involve themselves in changing their fate. Supervised by the head of rusunawa management and some pioneers, many (shortly/periodically) programs are implemented, although the mindset of marginalized people cannot be changed immediately. However, among the community, women are more cooperative and leading in managing the program. Through feminist intuition- some women initiate to raise awareness. In contrast to masculine domination taking advantage of the structure/policy given, some women try to reform the new order from a woman's perspective. Moreover, during the interaction process between women and the community, a dialectical process has begun to present often. By doing so, those women can maximize their role.

The research starts from the assumption of the roles of the actors/informants in shaping a social change within the community. In such situations, most people are unable to change lifestyles readily until some individuals/subjects - driven by high awareness strived to make a change through sustainable efforts. Also, from the perspective of social communication, one should be able to act as a subject, making it possible to create any breakthroughs. Similar situations and experiences in the past, which in this case, moving from marginalized place to systematical area, influence them to be initiators of social change. To lead rusunawa community, women should solve the problem without depending on men. Thus, this phenomenon can also be seen from a feminist perspective as feminine transformative leadership.

Women as Opinion Leaders within Community (A Model of Feminism Perspective) 
What makes this research different is the emphasis that empowerment leads the transformation process within the oppressed community that systematically belongs to the domination of masculine. Most of the previous studies focused on woman's struggling over the discrimination of color. The themes are varied, ranging from women in managerial work (Billing and Alvesson, 2000), female worker in mine sector (Mahmudah, 2019), female migrant workers (Rahardjo, Dwiningtyas and Pradekso, 2018), the dominance of patriarchy in International Non-Governmental Organization (Mosedale, 2014); over nation's sovereignty (Ardill, 2013); to radical feminism (Mackay, 2015). Feminism has also a long tradition and a diverse perspective (Miller, 2005). It ranges from Liberal Feminism, Marxist Feminism, Radical Feminism, Psychoanalytic Feminism, Contemporary Socialist Feminism, Existential Feminism, Postmodern Feminism, and Cultural Feminism.

One that is significant to the research is Crotty (2006) that used feminist epistemology to refer to Rosemarie Tong's (1997) form of feminism, although the use of the word "epistemology" in this context is problematic. 'Feminine epistemology' can be understood in another sense - one that suggests, not that woman know in a way fundamentally different from that of men, but that they theorize the act of knowing in a way different from that of men. In 'doing' epistemology, they express concerns, raise issues, and gain insights that are not generally expressed, raised, or gained by male epistemology. Again, 'feminine epistemology' insists that a woman's knowledge is in important respects, different from that of man. Fonow \& Cook (2005) concluded that epistemology means "the study of assumptions about how to know the social and apprehend its meaning." Likiwise, Farganis (1986) agreed that feminism is a movement to change the way one looks at the world, and feminist theory is part of that struggle.

In specific, summarized by Potter (2006), feminism depends on the assumption in which power refers to masculine so that the process of decision making is created for and by the masculine. Finally, there is a normative policy to change the system in fulfilling the female's access. Jónasdóttir and Jones (2008) claimed as the exclusivity of men; while Babbie (2013) and Gilligan (1993) mentioned that the experience between males and females was different from social reality about gender and thinking.

For this reason, therefore, feminist researchers who are active in voicing women's voices and trying to improve a perspective oriented to male domination, reject the claims of free-value positivist. Instead, assuming differences in women's subjective experience, interaction and collaboration with people who study until reaching personal relationships are essential. Feminism sees the world as an interconnected network of human relations.

Stressed by Rakow and Wackwitz (2004), three criteria should be distinguished:

1. Feminist communication theory theorizes gender

2. Feminist communication theory theorizes communication

3. Feminist communication theory theorizes social change

Feminist Communication Theory begins with the goals of understanding and explaining gender, refusing to accept stock answers, and unchallenged common-sense assumptions. It does not start with a hypothesis about or definition of communication, as does (ironically) most of the work in the field of communication, including that done by many feminist activists. Instead, understanding and explaining communication, like understanding gender, are key outcomes anticipated by work. Finally, unlike most of the other fields, which presume the continuation of the social order, feminist communication 
theory begins with the assumption that we need comprehensive structural change to produce new social relations and just societies.

Rakow and Wackwitz (2004) set the above criteria to become the main properties of feminist communication theory. Unlike most traditional communication theory, however, feminist communication theory is explanatory, political, polyvocal, and transformative. Feminist communication theory is explanatory. It speaks of and to experience. It seeks to make connections between concepts and lived experience, between observation and knowledge and thought and action. Then, feminist communication theory is political. It is assumed that the world is unjust and requires change. It is still found that women and others are invisible or devalued to understand the subordination. Women's voices are silenced in so many ways that the simple act of speaking may itself become a political act.

Next, the feminist communication theory is polyvocal. It is generated by multiple voices and experiences, with sometimes conflicting interpretations of reality. There is also involved participation from both disparate and similar voices, feminist communication theory is characterized by a multiplicity of perspectives, methods, forms, and forums. Feminist communication theory, therefore, simultaneously draws communities of feminists together and inspires dissent. Lastly, feminist communication theory is transformative. It contributes to intellectual and spiritual growth by providing different perspectives through which to conceptualize experiences and the structures of society. It promotes the transformation of thought and inspires action by helping individuals and groups make sense of communication practices and the realities they engender.

The other worth research to mention here is some scientific findings related to women's role as a leader. Fisher and Robbins (2015) discussed embodied leadership; Eagly and Heilman (2016) compiled a variety of leadership; Sarros, Cooper, and Hartican (2006) talk about leadership and character; also, Baxter (2018) found women leaders and gender stereotyping.

\section{Methodology}

This research used a qualitative framework, and as stated by Cooper and White (2012) this research is concerned with:

[...] the understanding or description of a phenomenon or event, one of the qualities of this type of research is its ability to generate descriptive data - thick description - that aids in the interpretation of the data, the findings and the result the understanding or description of a phenomenon or event, one of the qualities of this type of research is its ability to generate descriptive data - thick descriptionthat aids in the interpretation of the data, the findings and the results implied by the research. Consequently, a qualitative researcher tends to analyze data inductively. [...] qualitative researcher relies on his/her judgment, experience, history, social context, and construction of reality in order to generate new or to enhance existing perceptions of events and condition in the real world [...]"

To fulfill that requirement, this research requires observation and in-depth interviews. In detail, Salim (2006) explained that the positions of the researcher can be divided into passive involvement; partly involvement; active involvement; and 
full/complete involvement. Besides that, to gain accurate data in the field, the researcher should use in-depth interviews, mostly the unstructured ones. It is useful for harmonizing relationships with all informants. The aim is to take a role as an informant to understand social situation based on own perspective.

In qualitative research, the process of analysis itself has been begun during the process of data collection. As a case study, row data (field notes) will be analyzed by using coding. Neuman (2013) categorized three kinds of coding into open coding, axial coding, and selective coding, which are explained into these informants:

Table 1. The Characteristics of Informants

\begin{tabular}{lll}
\hline Informants & \multicolumn{1}{c}{ Status } & \multicolumn{1}{c}{ Role } \\
\hline $1^{\text {st }}$ Mestikasari & $\begin{array}{l}\text { Housewife with two sons (non- } \\
\text { relocation program) }\end{array}$ & Pioneer in the education sector \\
$2^{\text {nd }}$ Nurkhasanah & $\begin{array}{l}\text { Housewife with four sons (non- } \\
\text { relocation program) }\end{array}$ & $\begin{array}{l}\text { Pioneer in the creative } \\
\text { economic sector }\end{array}$ \\
$3^{\text {st }}$ Mariamah & $\begin{array}{l}\text { Widow with some grandchildren } \\
\text { (target of relocation program) }\end{array}$ & As charismatic leader \\
\hline
\end{tabular}
(source: primary data)

\section{Results and Discussion}

Related to the theory, all informants are in line with these assumptions that feminist communication theory theorizes gender, communication, and social change, namely:

Understanding and explaining communication, like understanding gender, are key outcomes anticipated by work.

Since 2015 living at rusunawa, the first informant (Mestikasari)-born in Wonogiri, April $8^{\text {th }}, 1975$-found herself burdened in the education sector. In spite of having no formal degree in the education field, it did not prevent her from initiating education at rusunawa. This intention is proven by the establishment of PAUD (Pendidikan Anak Usia Dini/Early Childhood Education), which is an informal education program akin to kindergarten. After that, she ran 'PKBM' (Pusat Kegiatan Belajar/center for learning activity) — an acceleration program for those who are unable to continue previous formal education or having an incomplete formal education. The informant showed high concern to this sector due to the number of children who dropped out of school in the rusunawa environment. Refusing to be known as the leader of PKBM, the informant chose herself to be a part of the board members in preparing and managing all programs affiliated to the government curriculum. She set another man (mentor) to be noted as the leader rather than pick herself up for the top position. By doing so, the first informant tried not to be dominant over the man. Practically, this informant initiates and fights for all efforts to promote the rusunawa community to get a better education.

The second informant is Nurkhasanah-born in Brebes/May 1, 1975. The following informant appeared to come forward among the community. Her Skill and creativity had opened many opportunities for her in the economic sector. This informant directly coordinated some programs and distributed them to the member of the community. Indubitably, this informant's involvement helped homemakers to increase family income by producing handicrafts. Jakarta Creative Hub $(\mathrm{JCH})$ is one of the agencies that had 'engaged' in this actor in some events. Being actively involved and had 
the willingness to change society, this informant became more productive and gained more achievements alongside the recognition.

As a mentor, this informant took responsibility to manage and also evaluated the whole process completed done by all members. To stimulate the performance of the members, the informant provided wages as a reward. The amount received by each person will be determined from the outputs. At least, those efforts are sufficient enough to motivate members to work better, to produce qualified products. Fortunately, sustainable efforts had empowered women to fulfill their household's needs and increase income. Other women can imitate her leadership at rusunawa.

One of the informant's experiences can be pointed through this dialogue:

"Yang sudah jahit, gak dibayar. Termasuk nenek tadi, ada 10 baju, belum dibayar. Soalnya kan yang order sudah kecewa sampe sekarang belum diambil karna kesel kan. Kemaren kurang berapa baju, gitu. Emang saya akui, yang paling bawel di grup itu, saya. Saya tuh, klo untuk hal-hal yang miring-miring, saya rewel. Kemaren pas di grup, saya bilang: Bu, ini kurang, tolong diberesin. Itu juga saya gak ngerjain, kan.. ada 20 pieces. Yang bisa jahit aja. Yang kurang bisa, dapet 1 baju. Dia menyerahkan ke saya, kerjaan belum selesai, ya saya emosi juga. Akhirnya, saya panggil: tolong dong diselesain. Meskipun saya gak ngelibatin di order-an itu, kan saya kesel juga. Pas sudah selesai, yang terima order-an itu agak marah juga. Jahitannya gak beres. Padahal kalo jahitannya jalan, order-an jalan terus."

So that, having competent to communicate for problems occurred, undoubtfully, her achievements strengthen the position of this informant to be a woman leader among the community.

Mariamah, the third informant, who was born on Moncokerto on November $11^{\text {th }}$, 1958, during her 40 years in Kalijodo, headed 248 people out of 87 families. This old single parent became an icon or symbol of strength among the residents of Kalijodo during her time as the head of the district. After executed to the rusunawa environment, in the beginning, the informant rejected to be re-elected as the leader for the ex-Kalijodo community. However, the informant won the election in March 2015, beating her competitor (a younger man).

The effort to build a dialogue was manifested through a variety of interactions involving the actor and community. In daily lives, interaction by dialogue/communication created an order in the same cultural perspective in which the majority of ex-Kalijodo communities come from, Javanese culture. Hence, the sameness of ethnicity strengthens a sense of belonging among the community. It had been run so long that the informant can persuade them, even till the relocation program was on execution. Until 2019, the informant decided to delegate other members of the community to be the next leader. By pursuing intensive dialogue among the community, the informant ensured new candidates to take the position as the new leader. The informant admitted that the regeneration process for young leaders must be prepared.

Feminist communication theory is explanatory, political, polyvocal, and transformative.

Come from an "isolated" area, Mariamah still brought her opinion based on reality experienced while living at Kalijodo, which has been discussed by Girsang (2017). There were many obstacles to adapt to the new environment. Pressured by the new system 
trigger problems in her community. The experience of leading the community for two periods (starting from 2012-2015 and 2015-2018) had shaped the character as a leader. The process of execution hits all Kalijodo community. Regardless of capital and job, they released home and property without any compensation from the government. In those difficult times, the informant struggled to make the community survive till settle at the new place, rusunawa. During her role as a leader, the actor actively coordinated to the management and encouraged people's participation in any activities held at the rusunawa environment.

Previously, the informant was ready in any pressing circumstances to deal with any parties, including the government and media. It is not easy to stay calm in such a tense situation; meanwhile, the informant was not young anymore. However, by prioritizing dialogue, it enabled the informant to go through all processes. The informant's legitimation was derived as a respected figure, at least within the Kalijodo community. The informant was still able to survive and control the situation calmly, even under repression. Through one negotiation to following, the informant showed that she could sit in equal with the government.

Also, in various opportunities through dialogue/negotiation, the informant was able to stand before the government party, in which men were dominant. Factually, this was an unequal condition when a woman fought for masculine power for the sake of a broader community. To emphasize this, the researcher referred to some results of the literature. One of them was done by Stuhlmacher and Walters (1999).

Related to gender differences in negotiation, women are more emotionally vulnerable when dealing with men. These are also revealed to the subject whose emotional bonding imprinted within the community becomes a strong basis for the third informant when dealing with the apparatus. The experience of togetherness in the past also affects the subject in making big decisions for the life of her community ahead.

Indeed, not all people - especially for unproductive/older women - would be able to carry out such tasks in stressful situations. The length of time in power positioning also could imply someone's expertise/ability. As a leader among the community, the credibility of this informant was undoubted. That is the recognition for the informant as a leader. Besides character, strong charisma is also inherent to the informant. Charm could also be built through power inside society itself. For the Kalijodo community, the informant's charm was so vital that it was shown through the attitude and value of humanity daily. The political arena became the informant's trajectory in implementing her involvement to determine the fate of the Kalijodo community. The peaceful transition from the original place (Kalijodo) to the new site (rusunawa) has been passed in a conducive way (without coercion) firmed the informant's capability as an opinion leader.

Another transformative effort also can be attached to other informants. Transformative efforts-through various breakthrough and creative movements-had been initiated and conducted by the other informant while living in the rusunawa environment. Adapted from previous research from Girsang (2018), below are summaries done by the informants: 
Table 2. The $1^{\text {st }}$ Informant's Role within the Community

\begin{tabular}{ll}
\hline No & Types of activity \\
\hline 1. & Giving tutorial \\
2. & Preparing student learning needs \\
3. & Developing administrative requirements in the learning and examination \\
& process \\
4. & Doing consultancy \\
5. & Providing moral support and solutions \\
6. & Acting as a supervisor at the time of the exam \\
7. & Looking for sponsorship \\
\hline
\end{tabular}

(source: primary data)

Table 3. The $2^{\text {nd }}$ Informant's Role in Economic Field

\begin{tabular}{ll}
\hline No & Types of activity \\
\hline 1 & Conducting initiation, supervision, and evaluation of programs/event \\
2 & Creating cooperation with internal leaders in the community \\
3 & Managing external relations with stakeholders (media, consumer) \\
4 & Empowering members by providing support, facilities and incentive/reward \\
5 & Providing open opportunities for members to participate in program/event \\
\hline
\end{tabular}

(source: primary data)

\section{Humans require a comprehensive structural change to produce new social relations and just societies.}

Living in a new environment, all informants struggled for change structure, change relations, and gain recognition. As an opinion leader, the informants put immense sacrifices to the community's needs. In line with the context of this article, the role of each subject was constructed by social and cultural factors. In other words, the dominance/determination of structure could be broken by the presence of agent/actor/informant in social practices (in which in rusunawa). This is also related to the social world which is inhabited as the construction of subjective and objective aspects (dualism between agent and structure).

As shown by the third informant - besides experience, social location also played a major role in knowledge development. Situated knowledge along her leadership period in Kalijodo particularly had enriched the informant's character. Moving to a new environment also would influence the knowledge shift possessed by the informant previously. In the process of transition, prior knowledge cannot be maintained wholly due to the new system at rusunawa.

The existing situation encouraged the informants in doing real actions for changing mindsets and behavior. By maximizing all capitals, the informants were considered as a new model in leadership based on the community needs. Through different experiences from the marginalized conditions (bitter experience) of relocation (in particular) people/targets, women's leadership was increasingly tested or has a place compared to masculine leadership. This marginalized perspective had critical power that was resistant to pressure and oppression. Feminine transformative leadership could show power relations by prioritizing improvised ways of life. Because feminine leadership is 
closer to a culture of collectivity that puts informants into the community and constructs the world and legitimates their role, so does the social changes that occur within the community that is built.

Women can emerge as agents of transformation in a new world order by giving ideas and breakthrough into their community. Experience and knowledge derived from marginalized situations and conditions refer to their actions based on the human side. Overall, the existing situation encouraged and shaped the informant's awareness to carry out reforms - especially in changing mindset and behavior. Appearing as the initiators by maximizing all they have will be the concern in pursuing the informants as new models in leadership based on community needs.

\section{Conclusion}

The research has reaffirmed the position of women by putting forward a more humanist leadership based on the informants in this research. The researcher categorized it as feminine transformative leadership, which can be implemented in community life bounded by the same social system. As a basic social leadership model of community, it is emphasized a phenomenon that occurs in urban society: a society that is moving towards social transformation. Amid these conditions, a small number of individuals aware, move and lead the process of change. They are female actors who contribute to the transformation process in a community like rusunawa.

\section{Acknowledgment}

The researcher would like to thank the research fund (Scheme: Doctoral Dissertation Research) from the Ministry of Research and Technology of the Republic of Indonesia in 2018.

\section{References}

Ardill, A. (2013) 'Australian Sovereignty, Indigenous Standpoint Theory and Feminist Standpoint Theory First Peoples' Sovereignties Matter', Griffith Law Review, 22(2), pp. 315-343. doi: 10.1080/10383441.2013.10854778.

Babbie, E. (2013) The Practice of Social Research. 13th edn. Wadsworth.

Baxter, J. (2018) Women Leaders and Gender Stereotyping in the UK Press. Cham: Palgrave Macmillan. doi: 10.1007/978-3-319-64328-1.

Billing, Y. D. and Alvesson, M. (2000) 'Questioning the Notion of Feminine Leadership: A Critical Perspective on the Gender Labelling of Leadership', Gender, Work and Organization, 7(3), pp. 144-157. doi: 10.1111/1468-0432.001030.

Cooper, K. and White, R. E. (2012) Qualitative Research in the Post-Modern Era. 1st edn. Springer Netherlands. doi: 10.1007/978-94-007-2339-9.

Crotty, M. (2006) The Foundations of Social Research. Meaning and Perspective in the Research Process. 1st edn. Canberra: Sage Publication Inc.

Eagly, A. H. and Heilman, M. E. (2016) 'Gender and Leadership: Introduction to the Special Issue', Leadership Quarterly, 27(3), pp. 349-353. doi: 10.1016/j.leaqua.2016.04.002.

Farganis, S. (1986) 'Social Theory and Feminist Theory: THe Need for Dialogue', Sociological Inquiry, 56(1), pp. 590-601. doi: 10.1111/j.1475682X.1986.tb00075.x.

Fisher, K. and Robbins, C. R. (2015) 'Embodied Leadership: Moving from Leader Competencies to Leaderful Practices', Leadership, 11(3), pp. 281-299. doi: 
$10.1177 / 1742715014522680$.

Fonow, M. M. and Cook, J. A. (2005) 'Feminist Methodology: New Applications in the Academy and Public Policy', Signs: Journal of Women in Culture and Society, 30(4), pp. 2211-2236. doi: 10.1086/428417 .

Girsang, L. R. (2017) 'Opini Perempuan sebagai Bagian Kelompok Masyarakat Pascaprogram Penertiban Pemukiman Kampung Pulo dan Kalijodo di Jakarta', in Prosiding Konferensi Nasional Komunikasi. Jakarta: Ikatan Sarjana Komunikasi Indonesia.

Girsang, L. R., Sihabudin, A. and Ronda, M. (2018) 'Indonesian Women's Struggle Towards Transformation: A Case from "Rusunawa" Community', Asian Social Science, 14(10), pp. 38-45. doi: 10.5539/ass.v14n10p38.

Jónasdóttir, A. G. and Jones, K. B. (2008) The Political Interests of Gender Revisited: Redoing Theory and Research with a Feminist Face. London: Manchester University Press.

Mackay, F. (2015) 'Radical Feminism', Theory, Culture \& Society, 32(8), pp. 332-336. doi: $10.1177 / 0263276415616682$.

Mahmudah, Z. (2019) 'Pekerja Perempuan di Tambang: Bentuk Negosiasi Kesetaraan Gender dalam Dunia Kerja Maskulin', Jurnal ASPIKOM, 3(6), p. 1228. doi: 10.24329/aspikom.v3i6.413.

Miller, K. (2005) Communication Theories. Perspective, Processes and Contexts. 2nd edn. New York: McGraw-Hill.

Mosedale, S. (2014) 'Women's Empowerment as a Development Goal: Taking a Feminist Standpoint', Journal of International Development, 26, pp. 1115-1125. doi: 10.1002/jid.3050.

Neuman, W. L. (2013) Metodologi Penelitian Sosial: Pendekatan Kualitatif dan Kuantitatif. 7th edn. Jakarta: PT Indeks.

Potter, E. (2006) Feminism and Philophy of Science. London: Routledge.

Rahardjo, T., Dwiningtyas, H. and Pradekso, T. (2018) 'Komunikasi "Penyesuaian Diri Kembali” Pekerja Migran Perempuan yang Kembali ke Daerah Asal', Jurnal ASPIKOM, 3(5), p. 817. doi: 10.24329/aspikom.v3i5.308.

Rakow, L. F. and Wackwitz, L. A. (2004) Feminist Communication Theory. Selections in Context. California: Sage Publication Inc.

Salim, A. (2006) Teori dan Paradigma Penelitian Sosial. 2nd edn. Yogyakarta: Tiara Wacana.

Sarros, J. C., Cooper, B. K. and Hartican, A. M. (2006) 'Leadership and Character', Leadership \& Organization Development Journal, 27(8). doi: 10.1108/01437730610709291.

Stuhlmacher, A. F. and Walters, A. E. (1999) 'Gender Differences in Negotiation Outcome: A Meta-analysis', Personnel Psychology, 52(3), pp. 653-677. doi: 10.1111/j.1744-6570.1999.tb00175.x.

Tong, R. (1997) Feminist Thought. A Comprehensive Introduction. London: Routledge. 